\title{
The year public health lost its soul: a critical view of the COVID-19 response
}

\author{
Damien Contandriopoulos ${ }^{1}$ (1)
}

Received: 31 May 2021 / Accepted: 23 September 2021 / Published online: 15 October 2021

(c) The Author(s) under exclusive license to The Canadian Public Health Association 2021

\begin{abstract}
The COVID pandemic was an acute test of public health capacities worldwide. Many will hail the successes obtained and stress the importance of the discipline. On the contrary, this commentary defends the idea that the COVID pandemic response forced public health to enter in a Faustian bargain with governments and realpolitik that threatens the very core of the discipline's principles.
\end{abstract}

\section{Résumé}

La pandémie de COVID a sévèrement mis à l'épreuve les capacités de santé publique à l'échelle mondiale. Nombreux sont ceux qui vont mettre de l'avant les succès obtenus pour défendre la centralité de la discipline. À l'inverse, le présent commentaire défend l'idée que la pandémie a poussé la santé publique à accepter un contrat faustien avec les gouvernements et le politique qui menace l'essence même des principes fondateurs de la discipline.

Keywords Public health $\cdot$ COVID $\cdot$ Theory $\cdot$ Politics

Mots-clés Santé publique $\cdot$ COVID $\cdot$ théorie $\cdot$ politique

The COVID pandemic is, at many levels, an historical turning point and, for some, the poster-child illustration of the usefulness and centrality of public health. My own understanding is radically different, and I contend that the pandemic pushed the field of public health in a Faustian bargain ${ }^{1}$ where it reneged on its core principles in a way that will have long-lasting implications.

\section{The "soul" of public health}

Public health, as a discipline, rests on three basic tenets. First, its goal of fostering individual and collective health and well-being implies benevolence. Second, interventions

\footnotetext{
1 The term "Faustian bargain" implies sacrificing one's values for power or material gain. It comes from a Middle Ages legend about Johann Georg Faust, a German alchemist who allegedly sold his soul to the devil in exchange for infinite knowledge and pleasures.
}

Damien Contandriopoulos

damien1@uvic.ca

1 School of Nursing, University of Victoria, PO Box 1700 STN CSC, Victoria, BC V8W 2Y2, Canada ought to rest on principles tested through scientific approaches. Finally, as the discipline evolved during the twentieth century, equity became its third core pillar: interventions should aim at reducing health disparities between individuals and between groups. Over time, the discipline also developed a tendency to debate how many angels can dance on the head of a pin, so any simple definition could certainly be discussed and debated. Nevertheless, few would contest that being equity-driven, evidence-based, and benevolent are central to the very nature of public health.

However, public health is not only a scientific discipline, it also is an applied practice, mostly taking place through specialized state bureaucracies. From national public health agencies to regional or local public health units, public health is firmly embedded in the state administrative apparatus. This operationalization of public health as a function of the state always had to contend with specific challenges deriving from its relations with governments and politics. Especially since, given the existing evidence on the social determinants of health, taken seriously, few goals would be as politically disruptive and subversive than trying to reduce health disparities. State-run public health 
bureaucracies therefore always had to carefully thread the line between their disciplinary ambitions and the political acceptability of their interventions. The resulting modus vivendi varied between jurisdictions but generally did not involve renouncing to the core tenets described above as much as being selective in their translation into practices and recommendations. As a side note, it is plausible that public health disciplinary fondness for intensely scholastic debates around equity and evidence-based policy stems, in part, from the double bind its applied arm must contend with.

\section{And then came COVID...}

Over the past decades, many events, from communicable diseases like HIV and Ebola to noncommunicable epidemics such as tobacco and opioid-related deaths, challenged the connection between public health disciplinary tenets and its applied arm constraints. But none of these challenges came close to the disconnects that COVID brought.

In early 2020, public health state bureaucracies everywhere suddenly found themselves working hand-in-hand with governments to draft unprecedented emergency measures to control COVID transmission. Over the following year, this emergency period slowly turned into odd symbiotic relations between political powers and public health structures.

Most jurisdictions in Western countries adopted "balanced-containment" strategies regarding COVID. This approach is characterized by the ambition to balance, on the one hand, the number of coronavirus infections, hospitalizations, and deaths and, on the other hand, the economic and social disruptions caused by strict infection control measures such as lockdowns (Oliu-Barton et al., 2021). The balancedcontainment approach is different from the COVID-zero or elimination approach adopted by Atlantic provinces, New Zealand, China, and others. It is also different from the morbid laissez-faire tried in Brazil and some US states.

Initial infection control measures implemented at the onset of the pandemic were drafted in the absence of strong evidence on transmission routes for the new coronavirus. For historical reasons (Molteni, 2021), the emphasis was on fomite and respiratory droplets. However, this focus ended up being misguided. By the summer of 2020, it became clear that the virus was likely airborne and by early 2021 the scientific consensus was that most COVID cases were caused by aerosol transmission (Allen \& Ibrahim, 2021; Tang et al., 2021). However, it also soon became clear that most Western state-run public health bureaucracies-as well as international public health bodies such as the WHO-actively defended erroneous initial theories on COVID transmission long after it was rational to do so. Instead of working toward the development and communication of evidence-based
COVID prevention strategies, public health institutions found themselves stonewalling and actively contradicting scientific developments in the field (Greenhalgh et al., 2021).

Over the same period, the focus of containment strategies shifted. Economic actors impacted by lockdowns and infection control measures successfully convinced many governments to slowly push the balance of the containment strategies toward looser infection control measures and the acceptance of higher infection rates. The reference point of balanced-containment strategies slowly shifted from minimizing cases to optimizing intensive care bed occupancy rates near or above $100 \%$. The combination of outdated and misguided infection prevention advice and looser restrictions contributed to fuelling higher and higher waves of cases.

In the meantime-and unsurprisingly - the balancedcontainment strategies were also shown to be deeply inequitable. Both the incidence and relative risk of death from COVID were highly correlated with income, social status, and racialized status (Karmakar et al., 2021). The likely reasons being that people in high-incidence groups were also the ones whose work could not be done remotely, who were exposed through high-risk occupations (Middleton et al., 2020), living in higher-density tenements, and not having much of a choice in those matters. The weaker infection control measures were, and the further they were pushed toward the maximization of economic activity, the worse the impact on equity.

By early summer 2021, some jurisdictions-such as Western Canada, the United Kingdom, and many US states-decreed that the pandemic was over and that prevention measures were not needed anymore. Those decisions, explicitly endorsed and defended by public health officials, were announced while international evidence on the transmissibility and immune evasion capacity of the Delta variant showed that vaccination alone would not prevent further waves of infection. Like clockwork, those "reopening" plans (Bell, 2021; Lafontaine, 2021; Wyton, 2021) paved the way to a brutal $4^{\text {th }}$ wave. A situation made worse by the fact prevention advice remained anchored in debunked theories about droplets and that few (if any) effective prevention measures-such as improved ventilation of indoor public spaces, advice on good masking techniques, and limits on large indoor gatherings-were implemented.

\section{The Faustian bargain}

In most Western countries, and in the majority of Canadian provinces, the COVID response symbiotically produced by political actors and public health institutions caused multiple disconnects: between the scientific evidence on COVID transmission and the public health sanctioned advice; between public health and governmental 
discourses prioritizing the well-being of the population and containment strategies focused mostly on economic indicators; and between inclusive discourses putting forward collective sacrifices for a common good and deeply inequitable interventions.

At the time of writing this commentary, those disconnects have grown too deep to be hidden. More efforts seem to go into controlling the political spin and rationing the information made available than in trying to correct documented deficiencies (Daflos, 2021; Thomas \& Gervais, 2021). This is not to say that there is no pushback by some public health officials and it could be that fierce debates are taking place behind closed doors. But in most jurisdictions, there has been little to no place for open dissension (Deep Singh, 2021).

Somewhere in the last year, public health lost its soul. The goal of fostering individual and collective health and well-being became secondary to disputable economic growth indicators and radical utilitarianism regarding the value of human lives. The focus on equity that was central in all public health discourses fell as one of the first victims of the discipline turn toward political symbiosis and realpolitik. The ambition to be a science-driven evidencebased practice continues to be daily trampled in evidencefree statements (Daflos, 2021; Goldman, 2020).

In the following months and years, we should expect the COVID pandemic to be used to support calls for increased budgets by public health state bureaucracies. And many valid arguments can be made in support of stronger public health. However, it would be a huge mistake to ignore what the discipline lost in the pandemic, and the causes explaining the disconnects discussed here. The pandemic caused public health to turn back to its medical roots instead of leveraging the interdisciplinarity it long preached (Greenhalgh et al., 2021). It pushed many public health state bureaucracies to become tools for governments instead of being carriers for evidence-based information. And more generally, it caused the discipline to renege on most of its principles.

Author contributions I wrote the commentary as a sole author. However, I want to thank Trish Greenhalgh and Mustafa Ozbilgin who provided numerous insights during informal discussions.

Data availability All materials used are in the public domain.

Code availability N/A.

\section{Declarations}

Ethics approval This commentary did not use data that require ethical approval.
Consent to participate N/A.

Consent for publication N/A.

Conflict of interest The author declares no competing interests.

\section{References}

Allen, J. G., \& Ibrahim, A. M. (2021). Indoor air changes and potential implications for SARS-CoV-2 transmission. JAMA, 325(20), 2112-2113. https://doi.org/10.1001/jama.2021.5053

Bell, R. (2021). Kenney's best summer ever to worst ICU numbers ever. Calgary Sun. Retrieved from https://calgarysun.com/opinion/colum nists/bell-kenneys-best-summer-ever-to-worst-icu-numbers-ever. Accessed 15 Sept 2021

Daflos, P. (2021). Reduced contact tracing, child vaccination debate revealed to B.C. doctors as province pushes return to normal. $C T V$ News Vancouver. Retrieved from https://bc.ctvnews.ca/reduced-conta ct-tracing-child-vaccination-debate-revealed-to-b-c-doctors-as-provi nce-pushes-return-to-normal-1.5586795. Accessed 15 Sept 2021

Deep Singh, K. (2021). As India's lethal COVID wave neared, politics overrode science. The New York Times. Retrieved from https://www. nytimes.com/2021/09/14/world/asia/india-modi-science-icmr.html? smtyp $=$ cur\&smid $=$ tw-nytimes. Accessed 15 Sept 2021

Goldman, E. (2020). Exaggerated risk of transmission of COVID-19 by fomites. The Lancet Infectious Diseases, 20(8), 892-893. https://doi. org/10.1016/S1473-3099(20)30561-2

Greenhalgh, T., Ozbilgin, M., \& Contandriopoulos, D. (2021). Orthodoxy, illusio, and playing the scientific game: a Bourdieusian analysis of infection control science in the COVID-19 pandemic. Wellcome Open Research, 6(126). https://doi.org/10.12688/wellcomeopenres.16855.1

Karmakar, M., Lantz, P. M., \& Tipirneni, R. (2021). Association of social and demographic factors with COVID-19 incidence and death rates in the US. JAMA Network Open, 4(1), e2036462-e2036462. https:// doi.org/10.1001/jamanetworkopen.2020.36462

Lafontaine, A. (2021). mer of hubris has led Canada's health systems to the verge of collapse. The Globe and Mail. Retrieved from https://www. theglobeandmail.com/opinion/article-a-summer-of-hubris-has-ledcanadas-health-systems-to-the-verge-of/?. Accessed 17 Sept 2021

Middleton, J., Reintjes, R., \& Lopes, H. (2020). Meat plants-a new front line in the COVID-19 pandemic. BMJ, 370, m2716. https://doi.org/ 10.1136/bmj.m2716

Molteni, M. (2021). The 60-year-old scientific screwup that helped COVID kill. Wired, May 13, 2021. Retrieved from https://www. wired.com/story/the-teeny-tiny-scientific-screwup-that-helpedcovid-kill/. Accessed 28 May 2021

Oliu-Barton, M., Pradelski, B. S. R., Aghion, P., Artus, P., Kickbusch, I., Lazarus, J. V., . . Vanderslott, S. (2021). SARS-CoV-2 elimination, not mitigation, creates best outcomes for health, the economy, and civil liberties. The Lancet, Online first. https://doi.org/10.1016/ S0140-6736(21)00978-8

Tang, J. W., Marr, L. C., Li, Y., \& Dancer, S. J. (2021). Covid-19 has redefined airborne transmission. BMJ, 373, n913.

Thomas, B., \& Gervais, B. (2021). Hinshaw believes 'Open for Summer' plan led to current spike in COVID cases. Calgary Herald. Retrieved from https://calgaryherald.com/news/local-news/hinsh aw-believes-open-for-summer-plan-led-to-current-spike-in-covidcases. Accessed 15 Sept 2021

Wyton, M. (2021). BC to stay the course on reopening plan despite rise in cases. The Tyee. Retrieved from https://thetyee.ca/News/2021/ 08/05/BC-Stay-Course-Reopening-Plan/. Accessed 15 Sept 2021

Publisher's note Springer Nature remains neutral with regard to jurisdictional claims in published maps and institutional affiliations. 